\title{
Current Considerations for Dental Ceramics and Their Respective Union Systems
}

\author{
Jefferson David Melo de Matos, ${ }^{1}$ Leonardo Jiro Nomura Nakano, ${ }^{1}$ Marco Antonio Bottino, ${ }^{1}$ Ricardo Huver de Jesus, ${ }^{2}$ Lucas Campagnaro Maciel ${ }^{2}$ \\ ${ }^{1}$ Department of Dental Materials and Prosthodontics, Institute of Science and Technology, São Paulo State University (Unesp), São José dos Campos, SP, Brazil \\ ${ }^{2}$ Department of Dentistry, School of Dentistry of Multivix, Multivix College, Vitória, ES, Brazil \\ - Conflicts of interest: none declared.
}

\section{Abstract}

Objective: to evaluate the main characteristics of dental ceramics, resin cements, surface treatments and verification of their failure modes, in relation to the literature and their respective clinical uses. Material and Methods: a bibliographic search was conducted in the main health databases PUBMED (www.pubmed.gov) and Scholar Google (www.scholar.google.com.br), in which studies published from 2002 to 2020 were collected. Laboratory studies, case reports, systematic and literature reviews, which were developed in living individuals, were included. Therefore, articles that did not deal with the main characteristics of dental ceramics, resin cements, surface treatments and verification of their failure modes, in relation to the literature and their respective clinical uses were excluded. Results: ceramics can be classified into glass-matrix ceramics, polycrystalline ceramics and hybrid ceramics. Just as there are different compositions of ceramics and bonding agents, there are also some surface treatment protocols that vary according to the choice of these materials. Conclusion: several ceramic systems are available, making professionals in the prosthetic area need a constant update about their properties and indications, since good results are not due exclusively to the type of material used, but also to the selection of the best material, type of preparation, professional's skill, resin cements, surface treatments and verification of their failure modes. In this context, further studies are needed in relation to dental ceramics and their proper clinical use.

Keywords: Ceramics; Dental materials; Dentistry.

\section{Introduction}

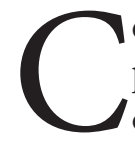
eramics are inorganic materials with non-metallic properties formulated for numerous purposes. ${ }^{1}$ In dentistry, they are materials of choice for aesthetic and functional restorative treatments, as they have high compression and wear resistance, chemical stability, biocompatibility, favorable aesthetics, translucency, fluorescence and coefficient of thermal expansion similar to the natural tooth.,

Conventional ceramics constitute a complex structure with crystalline nuclei not incorporated into the glass matrix, which reinforce the structure by forming a framework. These ceramics are characterized as vitreous because they have a greater amount of feldspar in their composition. Its composition presents a silica network $\left(\mathrm{SiO}_{2}\right)$, potassium oxide feldspar $\left(\mathrm{K}_{2} \mathrm{O}, \mathrm{Al}_{2} \mathrm{O}_{3}, \mathrm{SiO}_{2}\right)$ and/or soda-feldspar $\left(\mathrm{Na}_{2} \mathrm{O}, \mathrm{Al}_{2} \mathrm{O}_{3}\right.$, $\mathrm{SiO}_{2}$ ). However, despite their excellent optical properties, due to their glassy and crystalline nature, their mechanical properties contraindicate their use in regions that receive high masticatory loads. ${ }^{1,2}$

In this context, there was a search to improve the mechanical resistance of ceramics with a composition that would guarantee a greater amount of the crystalline phase in relation to the glass phase. Leucite was one of the first materials used to compose the crystalline matrix of ceramics, in order to prevent the propagation of cracks when they were subjected to tensile stresses, however, its indication was limited to inlays, onlays, facets and unitary crowns ${ }^{3}$. In order to expand the indication of these ceramics for posterior single crowns and even fixed partial dentures, lithium disilicate and zirconia reinforced lithium silicate were incorporated into the composition of these materials. ${ }^{4}$

In addition to the ceramic systems already mentioned, several other systems are available for the most diverse indications. Current systems feature ceramics with excellent mechanical properties associated with improved optical reflection. ${ }^{1}$ Most of these ceramics are presented in prefabricated blocks, which gives some advantages, like high resistance to fracture, by guaranteeing a more compact and homogeneous material. ${ }^{4-6}$

Based on the large number of ceramic systems available, Gracis et al. $(2015)^{6}$ recently proposed a new classification for dental ceramics. This classification was based on its composition regarding the presence or absence of the glass phase and organic matrix, presenting itself as follows: the glass-matrix ceramics must present in their composition nonmetallic inorganic ceramic materials containing a glass phase; the group of polycrystalline ceramics must also have inorganic and nonmetallic materials, however, without the presence of the glass phase. Finally, the groups of the resinmatrix ceramics must present a polymer matrix containing predominantly inorganic refractory compounds.

Therefore, the aim of this study is to evaluate the main characteristics of dental ceramics, resin cements, surface 
treatments and verification of their failure modes, in relation to the literature and their respective clinical uses.

\section{Material and Methods}

A bibliographic search was conducted in the main health databases PUBMED (www.pubmed.gov) and Scholar Google (www.scholar.google.com.br), in which studies published from 2002 to 2020 were collected. Laboratory studies, case reports, systematic and literature reviews, which were developed in living individuals, were included. Therefore, articles that did not deal with the main characteristics of dental ceramics, resin cements, surface treatments and verification of their failure modes, in relation to the literature and their respective clinical uses were excluded.

Through bibliographic search 40 articles were selected, which 18 articles were extracted from PUBMED (www.pubmed.gov) and 22 Scholar Google (www.scholar. google.com.br), as previously reported (Figure 1). The following specific medical subject titles and keywords were used: Ceramics (DeCS/MeSH Terms), Dental materials (DeCS/MeSH Terms), Dentistry (DeCS/MeSH Terms).

\section{Results}

Ceramics can be classified into glass-matrix ceramics, polycrystalline ceramics and hybrid ceramics. ${ }^{6}$ Just as there are different compositions of ceramics and bonding agents, there are also some surface treatment protocols that vary according to the choice of these materials. Glass-matrix ceramics have high silica content and have an excellent aesthetic performance (feldspathic ceramics, leucite and lithium disilicate), therefore, the surface treatment of choice for this type of ceramic is conditioning with 5 to $10 \%$ hydrofluoric acid for internal surfaces of ceramic restorations, followed by silane application and a bonding agent such as cement. $^{7,8}$

\section{Dental Ceramics}

The first time that ceramics were used as dental material was in 1774 by chemist Alexis Duchateau and by dentist Nicholas Dubois, where they made teeth for a complete denture. Time later, new ways of using ceramics were patented and the manufacture of all-ceramic crowns on a platinum plate was made from the invention of the electric oven and low-melting porcelain. The introduction of ceramics

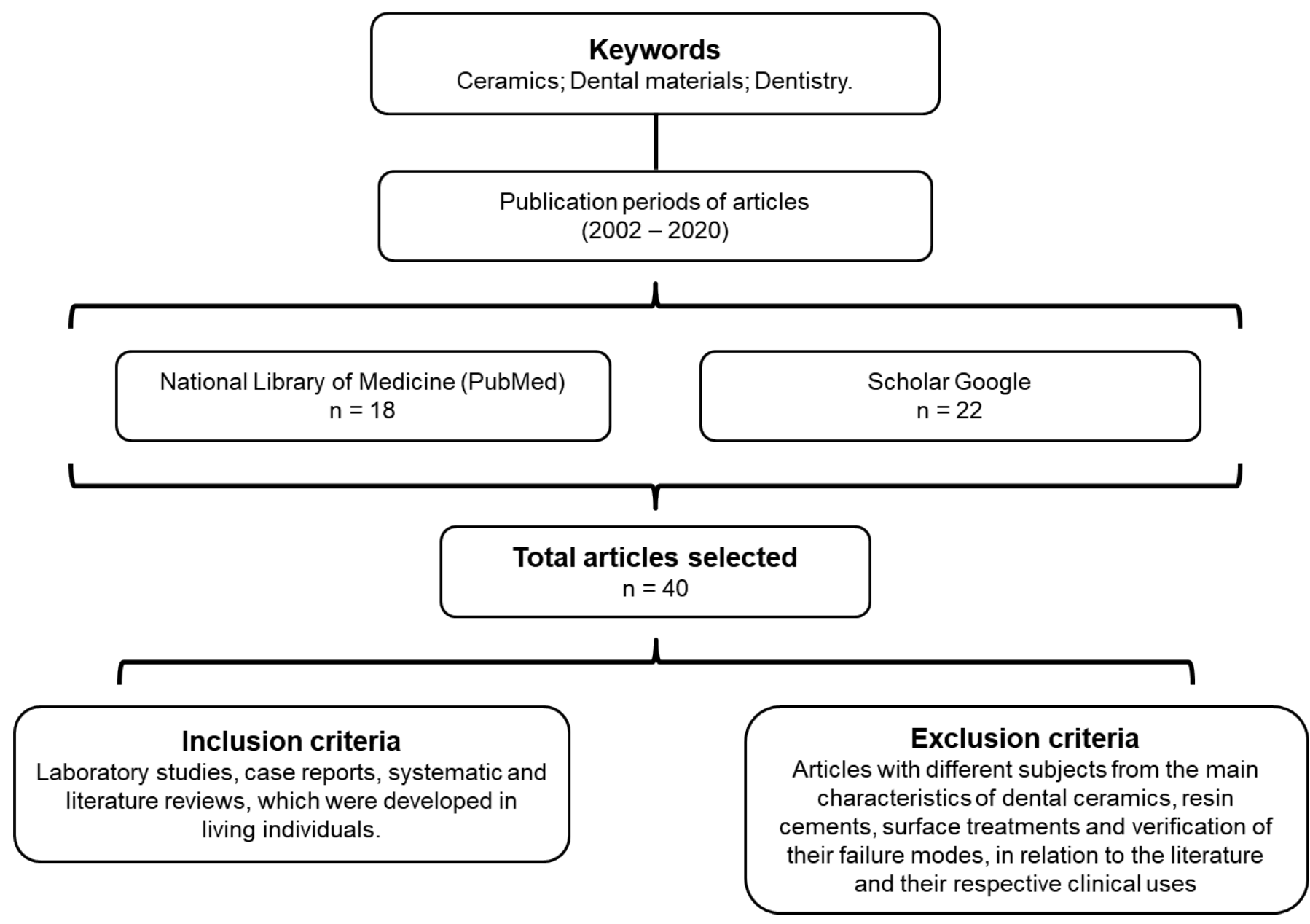

Figure 1. Articles selection flowchart. 
in restorative dentistry occurred in 1903 after the use of porcelain jacket crowns. ${ }^{9,10}$

Ceramic systems can be classified into two groups, which are acid-sensitive or conditioned and acid-resistant or non-conditioned. The first are the systems capable of being conditioned by acids. Silica is the only conditionable substance present in ceramics, part of this group has its composition based on silica, such as feldspathic porcelains and vitreous ceramics. ${ }^{11,12}$ Feldspar ceramic is defined as glass, composed of potassium feldspar and a small complement of quartz, when at high temperatures feldspar decomposes in a glassy phase and in a crystalline phase formed by leucite. ${ }^{13}$

The glass-matrix ceramics are translucent and therefore have a reflection of light close to that of the dental element, thus presenting an excellent optical quality favoring aesthetic restorations. They are susceptible to hydrofluoric acid conditioning and are classified as acid-sensitive, where associated with the application of the silane agent inside the restoration, it provides a high index of adhesion to the dental structure, also obtaining flexural strength. ${ }^{11,14}$

Panah, Rezai, Ahmadian ${ }^{15}$ also carried out a study showing that glass-matrix ceramics can be adhesive cemented, since they have silica in their composition, in this way, the chemical union with the resin cement is related to the previous application of silane, because some studies show that it positively influences the strength and union durability.

Feldspathic ceramics were the first to be manufactured in high fusion, with excellent aesthetic quality, the pure crowns of this material have been used for a long time, however, their low resistance limited their indication, therefore, they were used for single crowns in the anterior region due to little occlusal stress. ${ }^{16,12}$ In order to improve its resistance, these ceramics were reinforced with leucite, thus, its indication is also for jacket crowns of different types such as: opaque layer, dentin body, gingival dentin, enamel overlay and incisal enamel , metalloceramic and all ceramic restorations such as crowns, inlays, onlays and ceramics laminate veneers. ${ }^{8}$

Polycrystalline ceramics have different characteristics in relation to the glass-matrix ceramics, mainly for their superior mechanical properties and inferior aesthetic, caused by their high opacity. ${ }^{17}$ An example of this is the zirconias that have high hardness and tenacity, mainly used as framework, aesthetic coping and monolithic crowns for posterior teeth. This type of ceramic has a property called martensitic transformation, in which it is able to prevent the propagation of cracks by transforming the microstructure in a tetragonal to monoclinic phase. To improve this aesthetic need, there was the introduction of new zirconia, called translucent zirconia, which due to the change in its microstructure, through the increase in the amount of zirconia in the cubic phase, there was an improvement in translucency and aesthetics, but a reduction in resistance. ${ }^{18,19}$

\section{Resin Cements}

The cementation step in indirect restorations has a great clinical basis because the bonding agents are responsible for the union of dental remnant to the indirect restorative material. ${ }^{20}$

The ideal in a bonding agent is to be indissoluble in saliva and other oral agents, in addition to obtaining mechanical strength. When this material is integrated between the restoration and the prepared tooth, it provides retention and resistance in both parts, providing marginal blocking, benefiting the durability of prosthetic rehabilitation. ${ }^{21}$

All bonding procedure between the ceramic and the dental element is of great importance for the longevity of metalfree restorations, thus, knowing the best method of surface treatment, cementation technique and the material properties, leads to a greater prosthesis longevity. ${ }^{22}$

Several resin cements are currently available in the dental market, being them light-cured, chemical-cured, selfadhesive and dual-cured, where there is the presence of a tertiary amine..$^{19,13}$ Its main advantages are: low solubility, micromechanical and adhesive bonding, practically insoluble, high resistance, since when the piece is cemented, no matter how thin, the material acquires resistance, as it receives a reinforcement structure and high resistance compression. Regarding the disadvantages, it has sensitivity to humidity, polymerization process impeded in the presence of eugenol and relatively complex application technique. ${ }^{4}$

\section{Surface Treatment}

The result obtained through acid etching depends on the constitution and surface roughness of the dental element, the concentration of the applied acid and the etching time. ${ }^{24}$ Hydrofluoric acid is widely used to improve the mechanical bond between cement and silica-based ceramics. ${ }^{25}$ Therefore, to obtain adhesion between resin cement and ceramic, surface treatment is necessary. ${ }^{26}$

Acid conditioning increases the surface area and wettability, in addition to stabilizing the surface defects of the ceramic, enabling its reaction with the glass-matrix. Furthermore, it creates microporosities and micromechanical retentions, providing a more favorable irregular surface for the union..$^{27,11,28}$ According to the study by Xiaoping, Dongfeng and Silika, ${ }^{29}$ conditioning with hydrofluoric acid causes an increase in the roughness of the ceramic. In the study developed by Sundfeld et al., ${ }^{30}$ conditioning with $1 \%, 5 \%$ and $10 \%$ hydrofluoric acid was applied for 20 seconds where the $10 \%$ concentration showed the greatest removal of the glass phase.

There are several types of surface treatment, which can be applied to ceramics, among them the most common ones are sandblasting with aluminum oxide, lasers and application of hydrofluoric acid together with silane. For acid-sensitive ceramics, the association between conditioning with 
hydrofluoric acid and application of a silane bonding agent has promoted excellent bond strength and adhesive durability (mechanical and chemical bonding), a mechanism that is called silanization, which is essential for bonding ceramics, due to the promotion of a chemical bond between ceramics and resin. The chemical bond promoted by the silane agent is the main mechanism of adhesion of ceramics with resin cements. In contrast, acid-resistant ceramics have their bond strength benefited through abrasion by sandblasting with aluminum oxide particles. Through an adhesion mechanism, where a topographic pattern is created from silica-coated alumina particles, it allows micromechanical adhesion to the adhesive system and a chemical adhesion between the silica particles that covers the ceramic surface, silane and adhesive system. It is interesting to clarify that the alumina particles are capable of causing micro roughness for the micromechanical overlap with the cement. Thus, there is a deposition of silica particles on the ceramic surface. ${ }^{1,11,31}$

Adhesion to acid-sensitive ceramics is based on the chemical compatibility between silica and silane (chemical and micromechanical union). In this sense, sandblasting with aluminum oxide and silica on the acid-resistant ceramic surfaces appears as an alternative to improve the adhesion of resin cements and these ceramics. ${ }^{1,11}$

Currently, another method described in the literature for making the internal surface restoration rough is laser irradiation. Different types of lasers have been used in dentistry, as shown by Oliveira and Rabello. ${ }^{32}$ Within these, what stands out is the argon laser which is commonly used for its relatively low cost and good performance in creating roughness, it promotes the formation of active peroxide radicals that initiate chemical changes on the surface, even in inert materials, such as crystalline ceramics densely sintered, so they are generally indicated for treating acid-resistant ceramic surfaces. ${ }^{33}$

The acid reacts with the silica in the glass-matrix of this type of material, forming particles called hexafluorosilicate, removed from the surface of the restoration during washing with running water. After the use of the acid, the formation of micro retentive irregularities similar to "honeycombs" occurs, as shown by the Butze et al. ${ }^{34}$ studies.

Even though the surface treatment is a crucial step for a ceramic restoration, in the study by Valian and MoravejSalehi, ${ }^{35}$ it proves that it is not the only agent related to the bond strength between ceramic and resin cement. An important cause for the error of these prosthetic restorations is rupture, which is often related to the insufficient size of the ceramic, the shape of the support, the patient's occlusion, bonding agents and the internal failure of the restoration. ${ }^{36}$

Excessive conditioning with hydrofluoric acid can deteriorate the glass-matrix and cause weakness. In this case, it is important to know the conditioning time and the appropriate acid concentration to promote micromechanical retention without weakening the prosthetic restoration, as both the concentration and its time can lead to a weakening effect on the ceramic bonding. ${ }^{24,37-39}$

\section{Verification of Failure Mode}

In the study by Gomes et al., ${ }^{13}$ after the moment of rupture between cement/ceramics using the microshear test, the fracture interfaces were evaluated with $4 \mathrm{x}$ magnification optical microscope and the generated images were evaluated in image software to determine the type of failure: adhesive, when the failure only occurs on the ceramic surface; cohesive, when there is a failure in the restorative material (cement/ ceramic) and mixed when it presents both types of failures.

When Pereira et al. ${ }^{40}$ and Gomes et al. ${ }^{13}$ performed this type of analysis, only one group showed adhesive failure. The other sample groups showed mixed and cohesive failure in porcelain. Despite the similarity in the bond strength values between the groups in the shear test, there was a difference in the failure mode. The group treated with silane showed a higher frequency of cohesive failures in porcelain.

\section{Conclusion}

It can be concluded from this study that several ceramic systems are available, making professionals in the prosthetic area need a constant update about their properties and indications, since good results are not due exclusively to the type of material used, but also to the selection of the best material, type of preparation, professional's skill, resin cements, surface treatments and verification of their failure modes. In this context, further studies are needed in relation to dental ceramics and their proper clinical use.

\section{References}

1. Della Bona A, Anusavice KJ. Microstructure, composition, and etching topography of dental ceramics. Int J Prosthodont. 2002;15(2):159-67.

2. Figueiredo-Pina CG, Patas N, Canhoto J, Cláudio R, Olhero SM, Serro AP, et al. Tribological behaviour of unveneered and veneered lithium disilicate dental material. J Mech Behav Biomed Mater. 2016;53:226-38.

3. Monteiro JB, Oliani MG, Guilardi LF, Prochnow C, Rocha Pereira GK, Bottino MA, Melo RM, Valandro LF. Fatigue failure load of zirconia-reinforced lithium silicate glass ceramic cemented to a dentin analogue: Effect of etching time and hydrofluoric acid concentration. J Mech Behav Biomed Mater. 2018;77:375-382.

4. Romão RM, Lopes GRS, Matos JDM, Lopes GRS, Vasconcelos JEL, Fontes NM.

Causes of failures in ceramic veneers restorations: A literature review. Int J Adv Res. 2018;6(4):896-906.

5. Aurélio IL, Fraga S, Dorneles LS, Bottino MA, May LG. Extended glaze firing improves flexural strength of a glass ceramic. Dent Mater. 2015;31(12):e316-24. 6. Gracis S, Thompson VP, Ferencz JL, Silva NR, Bonfante EA. A new classification system for all-ceramic and ceramic-like restorative materials. Int J Prosthodont. 2015;28(3):227-35.

7. Peixoto NM, Matos JDM, Andrade VC, Bottino MA, Zogheib LV. Evaluación de la resistenciade unión de brackets ortodónticos fijados a cerámica de disilicato de litio. Int J Odontostomat. 2019;13(2):207-218. 
8. Amoroso AP, Ferreira MB, Torcato LB, Pellizzer EP, Mazaro JVQ, Gennari HF. Cerâmicas odontológicas: propriedades, indicações e considerações clínicas. Revista Odontológica de Araçatuba. 2012;33(2):19-25.

9. Bader JD, Shugars DA. Summary review of the survival of single crowns. Gen Dent. 2009;57(1):74-81.

10. Kelly JR, Benetti P. Ceramic materials in dentistry: historical evolution and current practice. Aust Dent J. 2011;56 Suppl 1:84-96.

11. Bottino MA, Faria R, Valandro LF. Percepção: estética em próteses livres de metal em dentes naturais e implantes. 1st ed. São Paulo(SP): Artes Médicas; 2009. 12. Namoratto LR, Ferreira RS, Lacerda RAV, Sampaio-Filho HR, Ritto FP. Cimentação em cerâmicas: evolução dos procedimentos convencionais e adesivos. Rev Bras de Odont. 2013;70(2):142-47.

13. Gomes TN, Matos JDM, Vasconcelos JEL, Olivieri KAN, Brandt WC, Miranda ME. Effect of Different Photoiniciers of Experimental Adhesive Systems on Adhesive Interface Union Resistance. Int Arch of Med. 2018;11(26):1-12.

14. Souza FC, Santos LR, Freitas AP, Silveira SRA, Lisboa MV, Lisboa JA. Influência do condicionamento ácido no reparo de cerâmicas odontológicas utilizando resina composta. Rev Baian de Odont. 2013;4(2):104-116.

15. Panah FG, Rezai SM, Ahmadian L. The influence of ceramic surface treatments on the micro-shear bond strength of composite resin to IPS Empress 2. J Prosthodont. 2008;17(5):409-14.

16. Krämer N, Reinelt C, Richter G, Frankenberger R. Four-year clinical performance and marginal analysis of pressed glass ceramic inlays luted with ormocer restorative vs. conventional luting composite. J Dent. 2009;37(11):813-9. 17. Heintze SD, Rousson V. Survival of zirconia and metal supported fixed dental prostheses: a systematic review. Int J Prosthodont. 2010;23:493-502.

18. Dos Santos DM, Moreno A, Vechiato-Filho AJ, Bonatto Lda R, Pesqueira AA, Laurindo Júnior MC, de Medeiros RA, da Silva EV, Goiato MC. The importance of the lifelike esthetic appearance of all-ceramic restorations on anterior teeth. Case Rep Dent. 2015;2015:704348.

19. Zhang F, Van Meerbeek B, Vleugels J. Importance of tetragonal phase in high-translucent partially stabilized zirconia for dental restorations. Dent Mater. 2020;36(4):491-500.

20. Bernardo RT, Obici AC, Sinhoreti MAC. Efeito da ativação química ou dual na microdureza knoop de cimentos resinosos. Rev Ciência Odont Bras. $2008 ;(11) 4: 80-85$.

21. Ribeiro CMB, Lopes MWF, Farias ABL, Cabral BLAL, Guerra CMF. Cimentação em prótese: Procedimentos convencionais e adesivos. Int J of Dent. 2007;6(2):58-62.

22. Bandeira AF, Lagustera CE, Sicoli EA, Mendonça MJ. Tratamento superficial de cerâmicas reforçadas in-ceram previamente aos procedimentos de cimentação adesiva - revisão de literatura. Revista RFO. 2008;13(1):80-85.

23. Gomes EA, Assuncao WG, Rocha EP, Santos PH. Cerâmicas odontológicas: o estado atual. Rev Cerâmica. 2008;54(54):319-325.

24. Santos LR, Tunes RS, Silveira SRA, Freitas AP, Lisboa JAA, Lisboa MV. O ácido fluorídrico na resistência ao cisalhamento entre cerâmica feldspática e resina composta. Ver APCD. 2015;69(1):62-67.

25. Venturini AB, Prochnow C, Rambo D, Gundel A, Valandro LF. Effect of
Hydrofluoric Acid Concentration on Resin Adhesion to a Feldspathic Ceramic. J Adhes Dent. 2015;17(4):313-20.

26. Brum R, Mazur R, Almeida J, Borges G, Caldas D. The influence of surface standardization of lithium disilicate glass ceramic on bond strength to a dual resin cement. Oper Dent. 2011;36(5):478-85.

27. Campos L, Telles M, Galhano GÁ, Camargo FP, Valandro LF, Mallmann A. Efeito do tempo de condicionamento da superfície cerâmica sobre a resistência adesiva entre uma cerâmica de fluorapatita e um cimento resinoso. Braz Dent Scienc. 2005;8(3):71-76.

28. Zogheib LV, Bona AD, Kimpara ET, McCabe JF. Effect of hydrofluoric acid etching duration on the roughness and flexural strength of a lithium disilicatebased glass ceramic. Braz Dent J. 2011;22(1):45-50.

29. Xiaoping L, Dongfeng R, Silikas N. Effect of etching time and resin bond on the flexural strength of IPS e.max Press glass ceramic. Dent Mater. 2014;30(12):e330-6.

30. Sundfeld D, Palialol ARM, Fugolin APP, Ambrosano GMB, Correr- Sobrinho L, Martins LRM, Pfeifer CS. The effect of hydrofluoric acid and resin cement formulation on the bond strength to lithium disilicate ceramic. Braz Oral Res. 2018;32:e43.

31. Della Bona A, Corazza PH, Zhang Y. Characterization of a polymer- infiltrated ceramic-network material. Dent Mater. 2014;30(5):564-9.

32. Oliveira PFG, Rabello TB. Tratamento de superfície para a cimentação adesiva de cerâmicas à base de zircônia: revisão de literatura. Rev Bras de Odont. 2017;74(1):36-39.

33. Colombo LMPC, Matafora FL, Moro AFV. Condicionamento de superfícies na Odontologia com plasma de argônio: uma revisão de literatura. Braz Dent Scienc. 2014;71(1): 85-8.

34. Butze J, Marcondes ML, Burnett-Júnior LH, Spohr AM. Avaliação da topografia superficial de cerâmicas submetidas a diferentes tratamentos de superfície. Rev Stomatos. 2011;17(32):4-14.

35. Valian A, Moravej-Salehi E. Surface treatment of feldspathic porcelain: scanning electron microscopy analysis. J Adv Prosthodont. 2014;6(5):387-94.

36. Freitas AP, Sábio S, Costa LC, Pereira JC, Franciscone PAS. Cimentação adesiva de restaurações cerâmicas. Salusvita. 2005;24(3):447-468.

37. Güler AU, Yilmaz F, Yenisey M, Güler E, Ural C. Effect of acid etching time and a self-etching adhesive on the shear bond strength of composite resin to porcelain. J Adhes Dent. 2006 Feb;8(1):21-5.

38. Soares ES, Silva JVP, Neppelenbroek KH, Jorge JJ, Urban VM. Tratamento de superfície de cerâmica pura para cimentação com cimentos resinosos. Rev de Odont da Unesp. 2009;38(3):154-160.

39. Prochnow C, Venturini AB, Grasel R, Bottino MC, Valandro LF. Effect of etching with distinct hydrofluoric acid concentrations on the flexural strength of a lithium disilicate-based glass ceramic. J Biomed Mater Res B Appl Biomater. 2017 May;105(4):885-891

40. Pereira ALC, Matuda LSA, Lima LG, Silva MFL, Morais-Sousa LK, Matos JDM, Vasconcelos JEL, Medeiros CR. Evaluation of thefluorescence of composite resins under an ultra violet light source. Int J Odontostomat. 2018;12(3):252-261.

\section{Mini Curriculum and Author's Contribution}

1. Jefferson David Melo de Matos - DDS;Phd student. Contribution: Design of the study, data interpretation, writing of case report and critical review and final approval. ORCID: 0000-0003-4507-0785

2. Leonardo Jiro Nomura Nakano - DDS;Phd student. Contribution: Data interpretation, writing of case report and critical review and final approval. ORCID: 00000001-6786-862X

3. Marco Antonio Bottino - DDS;Phd. Contribution: Writing of case report and critical review and final approval. ORCID: 0000-0003-0077-3161

4. Ricardo Huver de Jesus - DDS;Phd. Contribution: Design of the study, data interpretation, writing of case report and critical review and final approval. ORCID: 0000-0002-2905-8068

5. Lucas Campagnaro Maciel - DDS;Phd. Contribution: Design of the study, data interpretation, writing of case report and critical review and final approval. ORCID: 0000-0002-7687-4535 